\title{
The Effect of the Paleolithic Diet vs. Healthy Diets on Glucose and Insulin Homeostasis: A Systematic Review and Meta-Analysis of Randomized Controlled Trials
}

\author{
Małgorzata Jamka ${ }^{1}\left(\mathbb{D}\right.$, Bartosz Kulczyński $^{2}$, Agata Juruć ${ }^{3}$, Anna Gramza-Michałowska ${ }^{2}$, \\ Caroline S. Stokes ${ }^{4,5}$ and Jarosław Walkowiak ${ }^{1, * \mathbb{D}}$ \\ 1 Department of Pediatric Gastroenterology and Metabolic Diseases, Poznan University of Medical Sciences, \\ 27/33 Szpitalna Str., 60-572 Poznań, Poland; mjamka@ump.edu.pl \\ 2 Department of Gastronomy Sciences and Functional Foods, Faculty of Food Science and Nutrition, \\ Poznan University of Life Sciences, 31 Wojska Polskiego Str., 60-624 Poznań, Poland; \\ bartosz.kulczynski@up.poznan.pl (B.K.); anna.gramza@up.poznan.pl (A.G.-M.) \\ 3 Faculty of Health Sciences, State University of Applied Sciences in Konin, 4 Popiełuszki Str., 62-500 Konin, \\ Poland; agata.juruc@gmail.com \\ 4 Faculty of Life Sciences, Humboldt Universität zu Berlin, 14195 Berlin, Germany; \\ caroline.stokes@hu-berlin.de \\ 5 Department of Medicine II, Saarland University Medical Center, Saarland University, Kirrberger Str. 100, \\ 66421 Homburg, Germany \\ * Correspondence: jarwalk@ump.edu.pl; Tel.: +48-61-849-1432
}

Received: 23 December 2019; Accepted: 18 January 2020; Published: 21 January 2020

\begin{abstract}
Recently, the Paleolithic diet became popular due to its possible health benefits. Several, albeit not all, studies suggested that the consumption of the Paleolithic diet might improve glucose tolerance, decrease insulin secretion, and increase insulin sensitivity. Therefore, the aim of this meta-analysis was to compare the effect of the Paleolithic diet with other types of diets on glucose and insulin homeostasis in subjects with altered glucose metabolism. Four databases (PubMed, Web of Sciences, Scopus, and the Cochrane Library) were searched to select studies in which the effects of the Paleolithic diet on fasting glucose and insulin levels, glycated hemoglobin (HbA1c), homeostasis model assessment of insulin resistance (HOMA-IR), and area under the curve (AUC 0-120) for glucose and insulin during the oral glucose tolerance test were assessed. In total, four studies with 98 subjects which compared the effect of the Paleolithic diet with other types of diets (the Mediterranean diet, diabetes diet, and a diet recommended by the Dutch Health Council) were included in this meta-analysis. The Paleolithic diet did not differ from other types of diets with regard to its effect on fasting glucose (standardized mean difference (SMD): $-0.343,95 \%$ confidence interval (CI): -0.867 , $0.181, p=0.200$ ) and insulin (SMD: $-0.141 ; 95 \%$ CI: $-0.599,0.318 ; p=0.548$ ) levels. In addition, there were no differences between the Paleolithic diet and other types of diets in HOMA-IR (SMD: -0.151 ; 95\% CI: $-0.610,0.309 ; p=0.521$ ), HbA1c (SMD: $-0.380 ; 95 \%$ CI: $-0.870,0.110 ; p=0.129$ ), AUC 0-120 glucose (SMD: $-0.558 ; 95 \%$ CI: $-1.380,0.264 ; p=0.183$ ), and AUC 0-120 insulin (SMD: $-0.068 ; 95 \%$ CI: $-0.526,0.390 ; p=0.772)$. In conclusion, the Paleolithic diet did not differ from other types of diets commonly perceived as healthy with regard to effects on glucose and insulin homeostasis in subjects with altered glucose metabolism.
\end{abstract}

Keywords: Paleolithic diet; glucose; insulin; glycated hemoglobin; glucose metabolism disorders 


\section{Introduction}

Diabetes is a chronic disease and one of the most prevalent public health concerns globally. The current number of people suffering from diabetes exceeds 425 million in the world, and there is still a large number of people who remain undiagnosed [1]. Furthermore, many people do not meet the accepted criteria for diabetes [2], yet their blood glucose test results are too high to be considered as normal and, thus, they are diagnosed as being in the prediabetes stage. These subjects are very likely to go on to develop type 2 diabetes in the coming years if they do not change their eating habits. Diabetes and prediabetes can be screened based on plasma glucose criteria, either with fasting plasma glucose, 2-h glucose concentrations after an oral glucose tolerance test (OGTT), or glycated hemoglobin (HbA1c) criteria [1,2].

The American Diabetes Association's (ADA) recommendations strongly emphasize that there is no single eating pattern that is best for those with diabetes; however, they do suggest that the diet should mainly be based on products with a low glycemic index and should exclude refined sugars and processed food [2]. Many studies revealed that diets high in protein can improve diabetes-related parameters. For example, after a three-month intervention, Luger et al. [3] observed improvements in losing weight, fasting glucose, and insulin concentrations in a group of subjects consuming $30 \%$ energy from protein in comparison with the control group that consumed 15\% energy from protein. Results were comparable with a meta-analysis in which the participants with high-protein eating plans had 2-kg greater weight loss and $0.5 \%$ greater improvement in $\mathrm{HbA1c}$ [4]. The consumption of carbohydrate foods is also a crucial factor in patients with diabetes or in the pre-diabetes stage. Foods containing carbohydrates have a wide range of effects on the glycemic response because they differ in their proportions of sugars, starches, and fiber [5].

The Paleolithic diet, also known as a hunter-gatherer diet or stone-age diet, is an estimated nutritional pattern considered to be typical of people living during the paleolithic era, from approximately 2.5 million to 10,000 years ago. It encourages the consumption of meat, fish, eggs, vegetables, fruits, roots, and nuts, while many cultivated products, such as dairy products, oils, cereals, and legumes (as well as salt and refined sugars) are excluded [6]. A traditional Paleolithic diet contains an estimated 35\% of energy from fats, 35\% of energy from carbohydrates, and 30\% of energy from proteins. Therefore, the Paleolithic diet typically resembles a low-carbohydrate diet. However, the hunter-gatherer diet provides a higher amount of dietary fiber (up to 45-100 g per day) than a low-carbohydrate diet [7]. Recently, the Paleolithic diet received attention due to its possible health benefits [8]. Paleolithic nutrition is suggested to be associated with an improvement in lipid profile and with the reduction of blood pressure [8,9]. Moreover, this type of diet is suggested to have a positive impact on weight loss [10]. Additionally, it has anti-inflammatory benefits and might reduce oxidative stress [11]. It was also suggested that the Paleolithic diet might have a beneficial effect on carbohydrate metabolism and insulin homeostasis [8], thus making it relevant for patients with diabetes. However, the results of studies assessing the effect of the diet on glucose and insulin levels are ambiguous, with conflicting findings being reported [10,12-20].

Therefore, the aim of this meta-analysis was to compare the effect of the Paleolithic diet with other types of diets commonly perceived as healthy on glucose and insulin homeostasis in studies conducted in adults with altered glucose metabolism. Because altered glucose metabolism is frequently observed in subjects with metabolic syndrome and metabolic syndrome is also associated with a high risk of progression to type 2 diabetes mellitus [21], this meta-analysis also included studies in which the majority of participants had at least two characteristics of metabolic syndrome.

\section{Methods}

This systematic review and meta-analysis was carried out and reported in accordance with the guidelines of the Preferred Reporting Items for Systematic Reviews and Meta-Analyses (PRISMA, see Supplementary Materials) [22]. Prior to initiating the review process, the protocol was registered with PROSPERO, registration number: CRD42019126412 [23]. 


\subsection{Search Strategy}

PubMed, Web of Knowledge, Scopus, and the Cochrane Library databases were searched from time of inception until September 2019, using the following MeSH terms: ((("paleo diet" OR "paleolithic diet" OR "stone age diet" OR "caveman diet" OR "hunter-gatherer diet") AND ("insulin" OR "insulin resistance" OR "hyperinsulinism" OR "glucose metabolism disorders" OR "hypoglycemia" OR "hyperglycemia" OR "blood glucose" OR "diabetes mellitus" OR "glucose intolerance" OR "glucose tolerance test" OR "glycated hemoglobin A" OR "prediabetic state")) NOT "animals"). In addition, hand searches of the reference lists of included papers identified further potential studies not captured in the electronic database searches. No language restrictions were applied.

\subsection{Study Selection}

Original studies were included if they met the following inclusion criteria:

- Types of studies: randomized controlled trial (RCTs; parallel or crossover), irrespective of publication status;

- Types of interventions: Paleolithic diet (regardless of the duration of the intervention) versus another type of diet (e.g., the Mediterranean diet, diabetes diets, national dietary recommendation);

- Population: studies conducted in humans with glucose metabolism disorders (diabetes mellitus (criteria for the diagnosis: fasting plasma glucose concentrations $\geq 126 \mathrm{mg} / \mathrm{dL}(7.0 \mathrm{mmol} / \mathrm{L}$ ) or 2-h glucose levels $\geq 200 \mathrm{mg} / \mathrm{dL}$ (11.1 mmol/L) during OGTT or $\mathrm{HbA} 1 \mathrm{c} \geq 6.5 \%$ (in the absence of unequivocal hyperglycemia; for these parameters, diagnosis requires two abnormal test results from the same sample or in two separate test samples) or a random plasma glucose $\geq 200 \mathrm{mg} / \mathrm{dL}$ $(11.1 \mathrm{mmol} / \mathrm{L}))$, prediabetes state (impaired fasting glucose (fasting plasma glucose concentrations from $100 \mathrm{mg} / \mathrm{dL}(5.6 \mathrm{mmol} / \mathrm{L})$ to $125 \mathrm{mg} / \mathrm{dL}(6.9 \mathrm{mmol} / \mathrm{L}))$, or impaired glucose tolerance (2-h plasma glucose levels during OGTT from $140 \mathrm{mg} / \mathrm{dL}(7.8 \mathrm{mmol} / \mathrm{L})$ to $199 \mathrm{mg} / \mathrm{dL}(11.0 \mathrm{mmol} / \mathrm{L}))$ or $\mathrm{HbA} 1 \mathrm{c}$ from $5.7 \%$ to $6.4 \%$ ) [2], or studies which included participants where the majority had at least two characteristics of metabolic syndrome (waist circumference $\geq 102 \mathrm{~cm}$ for men and $\geq 88 \mathrm{~cm}$ for women, triglyceride levels $\geq 150 \mathrm{mg} / \mathrm{dL}$ ( $1.7 \mathrm{mmol} / \mathrm{L}$ ), high-density lipoprotein (HDL) cholesterol $<40 \mathrm{mg} / \mathrm{dL}(1.0 \mathrm{mmol} / \mathrm{L})$ for men and $<50 \mathrm{mg} / \mathrm{dL}(1.3 \mathrm{mmol} / \mathrm{L})$ for women, hypertension or blood pressure $\geq 130 / 85 \mathrm{mmHg}$, or fasting plasma glucose $\geq 100 \mathrm{mg} / \mathrm{dL}(5.6 \mathrm{mmol} / \mathrm{L})$ ) [24], with no restrictions on age, gender, and race/ethnicity of study participants, location of study, or sample size.

The exclusion criteria were as follows:

- Types of studies: non-RCTs, uncontrolled trials, observational studies (e.g., ecologic study, cohort study, case-control study, case reports, case series, editorials, commentaries, letters to the editor, qualitative research), conference papers, or publications available only in abstract form (no possible contact with authors);

- Population: studies conducted in animal models or studies performed in healthy subjects or a specific group of patients (e.g., pregnant or breastfeeding women).

Any RCTs that assessed the effect of the Paleolithic diet on glucose and insulin homeostasis qualified for consideration.

\subsection{Quality Assessment}

Three investigators (M.J., A.J., and B.K.) evaluated each article independently in the three main stages of the extraction process (Figure 1). Firstly, article titles were screened, followed by abstracts and finally full texts for eligibility for inclusion in the systematic review and meta-analysis. Disagreements were resolved by discussion between the investigators and included a discussion with two other authors (C.S. and J.W.) until a consensus was reached. All investigators agreed on the final decision 
of the studies to be included. Primary authors of relevant articles were contacted directly if the data sought were unavailable or if the study was only published in abstract form.

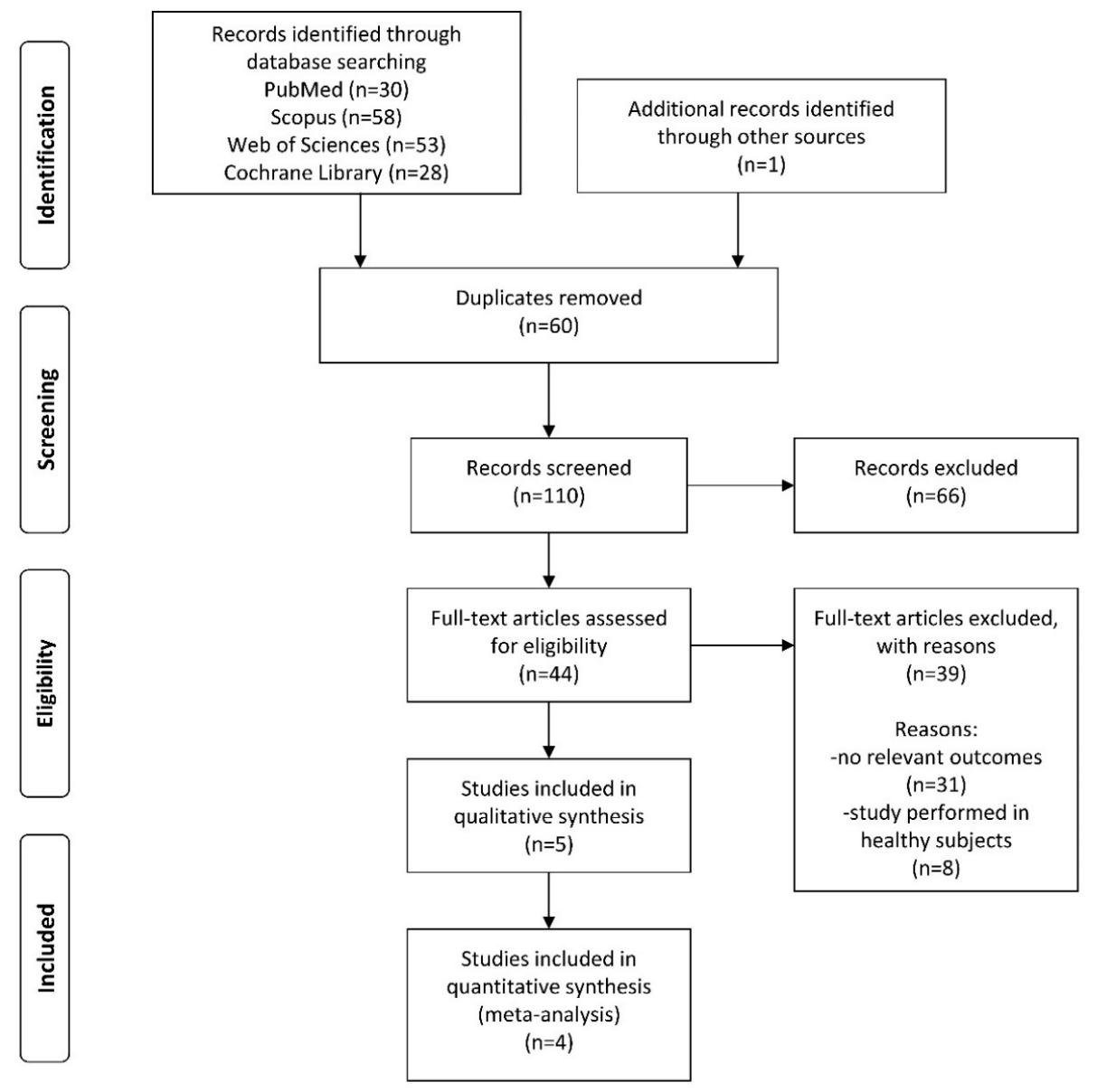

Figure 1. Process of the search.

\subsection{Data Extraction}

Eligible studies were reviewed, and the following data were independently extracted by three authors (M.J., A.J., and B.K.):

- General information: first author's name, publication year, country;

- Study characteristics: study design and method of blinding;

- Characteristics of study participants: sample size (total sample size and number of subjects in each group), age, sex, body mass index (BMI), body weight, ethnicity, and health status (diabetes mellitus type 1 , diabetes mellitus type 2 , impaired fasting glucose, and impaired glucose tolerance or other);

- Type of intervention: type of diet, the macronutrient composition of diet (the energy value of the diet, percentage energy from carbohydrate, protein and fat, dietary fiber intake (g/day)), recommended and excluded food products, time of intervention, duration of intervention;

- Pre- and post-intervention fasting glucose and insulin levels, $\mathrm{HbA} 1 \mathrm{c}$ values, the area under the curve (AUC; 0-120 min) for glucose and insulin during OGTT and homeostasis model assessment of insulin resistance (HOMA-IR).

\subsection{Risk of Bias}

Risk of bias was assessed independently by two authors (M.J. and A.J.) using the Cochrane Collaboration tool, where the following domains are included: selection bias, performance bias, 
detection bias, attrition bias, reporting bias, and other bias. Criteria for low risk, unclear risk, and high risk of bias per the Cochrane Handbook for Systematic Reviews of Interventions were used [25].

\subsection{Data Analysis}

Subjects were categorized according to the BMI cut-off (BMI = body weight $(\mathrm{kg}) /$ body height $\left.\left(\mathrm{m}^{2}\right)\right)$ values proposed by the World Health Organization for adolescents and adults [26]. According to these criteria, underweight was defined as BMI $<18.5 \mathrm{~kg} / \mathrm{m}^{2}$, normal body weight as $18.5-24.9 \mathrm{~kg} / \mathrm{m}^{2}$, overweight as $25.0-29.9 \mathrm{~kg} / \mathrm{m}^{2}$, and obesity as $\geq 30.0 \mathrm{~kg} / \mathrm{m}^{2}$.

The ADA recommendations [2] were used to assess fasting glucose and insulin levels, as well as AUC 0-120 for glucose and insulin. Impaired glucose tolerance is defined as plasma concentrations of glucose at $120 \mathrm{~min}$ in the OGTT ranging from 7.8 to $11.0 \mathrm{mmol} / \mathrm{L}$, while impaired fasting glucose is defined as fasting glucose levels from 5.6 to $6.9 \mathrm{mmol} / \mathrm{L}$, normal glucose tolerance is defined as glucose levels at $120 \mathrm{~min}$ in the OGTT $<7.8 \mathrm{mmol} / \mathrm{L}$, and normal fasting glucose is defined as fasting glucose levels ranging from 3.9 to $5.5 \mathrm{mmol} / \mathrm{L}$. Diabetes mellitus was diagnosed when fasting glucose levels were $\geq 7.0 \mathrm{mmol} / \mathrm{L}$ or glucose levels at $120 \mathrm{~min}$ in the OGTT were $\geq 11.1 \mathrm{mmol} / \mathrm{L}$ or $\mathrm{HbA} 1 \mathrm{c} \geq 6.5 \%$. A reference range for fasting insulin of $<174 \mathrm{pmol} / \mathrm{L}$ was assumed [27]. The changes in the HOMA-IR index during the intervention period were used to assess the alterations in insulin resistance within the studied populations. According to ATP III-Met, we defined cut-off values of HOMA-IR for the diagnosis of insulin resistance as $\geq 1.8$ [28].

\subsection{Outcomes}

Our primary outcomes were post-intervention fasting glucose, insulin levels, $\mathrm{HbA1c}$ values, and HOMA-IR index. Our prespecified secondary outcomes were AUC 0-120 for glucose and insulin.

\subsection{Statistical Analysis}

Data are presented as means \pm standard deviations (SD). We undertook data synthesis, including a calculation of effect sizes with $95 \%$ confidence intervals (CIs), using fixed-effects models (if no heterogeneity was present) and random-effects models (to analyze outcomes moderate and high with heterogeneity) with inverse variance weighting [29]. A meta-analysis of the studies was carried out when at least two studies were included that analyzed data for the specific outcome. Standardized mean differences (SMDs) were used as a summary statistic to allow comparison of effect sizes across studies. The SMD is estimated from the difference between the mean outcome values of the intervention and control groups divided by the pooled SD of the outcome values. Forest plots were generated to illustrate the study-specific effect sizes along with $95 \%$ CI [25]. Sensitivity analyses were also performed by removing each study one by one and recalculating the pooled estimates. Due to a small number of studies included in this meta-analysis, subgroup analysis was not performed.

Heterogeneity between studies was evaluated using Cochran $Q$ statistics; $p<0.1$ indicates significant heterogeneity. The $\mathrm{I}^{2}$ test was also used to evaluate consistency between studies in which a value $<25 \%$ indicates a low risk of heterogeneity, $25 \%-75 \%$ indicates a moderate risk of heterogeneity, and $>75 \%$ indicates a high risk of heterogeneity [30].

All analyses were performed using the Comprehensive Meta-Analysis software, version 3.0 (Biostat, Inc., Englewood, NJ, USA). A $p$-value $<0.05$ was considered to be statistically significant.

\section{Results}

\subsection{Search Results}

A flow chart of the selection process is shown in Figure 1. The electronic database search identified 110 publications, but screening titles and abstracts excluded 66 articles. The full texts of 44 papers were retrieved, of which 39 papers were excluded from the meta-analysis due to a lack of relevant outcomes or because the study included healthy subjects only. Consequently, four studies were included in this 
meta-analysis $[9,13,16-18]$, one of which had two references related to the same population and the same intervention but reported on different outcomes $[9,16]$.

\subsection{Characteristics of Included Studies}

The characteristics of the included studies are provided in Table 1. These studies were published between 2007 [17] and 2016 [16], and three of them were conducted as RCTs with parallel group designs $[13,17,18]$, whereas one study was designed as a crossover RCT $[9,16]$. The time of intervention ranged from two weeks [13] to 12 weeks $[9,16,17]$.

In the Paleolithic group, average energy intake varied from $1344 \pm 521 \mathrm{kcal}$ [17] to $2079 \mathrm{kcal}$ [13]. Protein provided from $24 \%$ [9,13,16] to $28 \%$ [17] of energy. In addition, $27 \%$ [17] to $41 \%$ [13] of energy came from fat. Intake of carbohydrate was in the range from $32 \%[9,13,16]$ to $40 \%$ [17] of energy. Fiber intake varied from $21.4 \pm 13.2 \mathrm{~g}$ [17] to $34 \mathrm{~g}$ per day [13]. One study did not provide information about total caloric intake and macronutrient composition of the diet [18]. In all included studies, the Paleolithic diet was based on lean meat, fish, fruit, vegetables, eggs, and nuts. The Paleolithic diet generally does not contain dairy products, cereal grains, legumes, refined fats, salt, and sugar. These products were also excluded from the Paleolithic diet in the included studies $[9,13,16-18]$.

In the control group, mean energy intake ranged between $1795 \pm 306 \mathrm{kcal}$ [17] and $2079 \mathrm{kcal}$ [13], while the average dietary macronutrient composition of the diets was as follows: protein $17 \%$ [13] to $20 \%[9,16,17]$ of energy, fat $25 \%$ [17] to $34 \%[9,16]$ of energy, and carbohydrate $42 \%[9,16]$ to $52 \%$ [17] of energy. Fiber intake ranged from $26 \pm 8 \mathrm{~g}[9,16]$ to $28 \mathrm{~g}$ per day [13]. In one study, the reference diet was based on the guidelines for a healthy diet of the Dutch Health Council [13]. In short, the guidelines recommend intake of more plant-based and less animal-based foods. A reduction of the intake of sugar-based beverages is also emphasized. In this study, the duration of the intervention was two weeks. In another study, the diabetes diet provided evenly distributed meals for 12 weeks with an increased intake of vegetables, root vegetables, wholegrain bread, and other wholegrain cereal products, fruits, and berries. Overall, the emphasis was on increasing dietary fiber, and decreasing intake of total fat with more unsaturated fat being used $[9,16]$. In another study, the control group received the Mediterranean diet for 12 weeks based on wholegrain cereals, low-fat dairy products, potatoes, legumes, vegetables, fruits, fatty fish, and refined fats rich in monounsaturated fatty acids and alpha-linolenic acid [17], while Masharani et al. [18] provided a diet based on recommendations by the ADA for three weeks. This diet consisted of cereal grains, dairy, or legumes, moderate salt intake, low-fat dairy, whole grains, and legumes.

In two studies, meals were supplied by researchers [13,18]. Boers et al. [13] designed both diets as seven consecutive daily menus (breakfast, lunch, dinner, and snacks). Masharani et al. [18] divided the diets into three meals and three snacks, all prepared by the research center kitchen staff. Participants ate some of the meals in the research center, and the rest of the meals were packed for take-out. In two other studies, participants received written dietary advice and food recipes $[9,16,17]$. In three studies, to ensure compliance with the intervention, subjects were requested to keep records of the food consumed $[9,13,16,17]$. In addition, in one study, subjects were encouraged every other day by telephonic contact with their personal coach to complete all meals and to discuss their progress, body weight fluctuation, possible physical and psychological discomforts, or adverse events [13]. In all studies, the emphasis was placed on the prevention of weight loss during the intervention $[9,13,16-18]$. However, at the end of the intervention period, body weight significantly decreased in both groups $(-1.5 \mathrm{~kg}$ vs. $-1.2 \mathrm{~kg} ;-5.0 \mathrm{~kg}$ vs. $-4.1 \mathrm{~kg} ;-0.9 \mathrm{~kg}$ vs. $-1.4 \mathrm{~kg})$ for three of the included studies $[9,16-18]$. In addition, two studies observed significant differences between post-intervention body weight, with lower body weight noted in the Paleolithic group $[9,13,16]$. 
Table 1. Nutrient and caloric composition of the dietary intervention.

\begin{tabular}{|c|c|c|c|c|c|c|c|c|c|c|c|c|}
\hline Study & Year & $\begin{array}{l}\text { Type of } \\
\text { Study }\end{array}$ & $\begin{array}{l}\text { Duration of } \\
\text { Intervention } \\
\text { (week) }\end{array}$ & Groups & Subjects $(n)^{\mathrm{a}}$ & Description & Energy (kcal) & Protein (\%) & Fat $(\%)$ & Carbohydrate (\%) & Fiber (g) & $\begin{array}{c}\text { Meals } \\
\text { Supplied by } \\
\text { Researchers }\end{array}$ \\
\hline Boers et al. [13] & 2014 & $\begin{array}{c}\text { RCT, } \\
\text { parallel }\end{array}$ & 2 & $\begin{array}{l}\text { Control } \\
\text { group }\end{array}$ & 14 & $\begin{array}{l}\text { Based on lean meat, fish, fruit, leafy } \\
\text { and cruciferous vegetables, root } \\
\text { vegetables, eggs, and nuts. Dairy } \\
\text { products, cereal grains, legumes, } \\
\text { refined fats, extra salt, } \\
\text { and sugar were excluded. } \\
\text { The reference diet was based on the } \\
\text { guidelines for a healthy diet of the } \\
\text { Dutch Health Council. }\end{array}$ & 2079 & 24 & 29 & 32 & 28 & Yes \\
\hline Fontes-Villalba et al. [16] ${ }^{\mathrm{b}}$ & 2016 & $\begin{array}{c}\mathrm{RCT}, \\
\text { crossover }\end{array}$ & 12 & $\begin{array}{l}\text { Control } \\
\text { group }\end{array}$ & 6 & $\begin{array}{l}\text { Paleolithic diet based on lean meat, } \\
\text { fish, fruits, vegetables, root vegetables, } \\
\text { eggs, and nuts. } \\
\text { Diabetes diet stated that it aimed to } \\
\text { provide evenly distributed meals with } \\
\text { an increased intake dietary fiber from } \\
\text { vegetables, root vegetables, } \\
\text { wholegrain bread, and other } \\
\text { wholegrain cereal products, fruits, } \\
\text { and berries, and a decreased intake of } \\
\text { total fat with more emphasis on } \\
\text { unsaturated fat. }\end{array}$ & $1581 \pm 295^{c, d}$ & $24 \pm 3^{c, d}$ & $39 \pm 5^{c, d}$ & $32 \pm 7^{c, d}$ & $21 \pm 8^{\mathrm{c}, \mathrm{d}}$ & No \\
\hline Jönsson et al. [9] ${ }^{b}$ & 2009 & $\begin{array}{c}\mathrm{RCT}, \\
\text { crossover }\end{array}$ & 12 & $\begin{array}{l}\text { Control } \\
\text { group }\end{array}$ & 7 & $\begin{array}{l}\text { Based on lean meat, fish, fruit, leafy } \\
\text { and cruciferous vegetables, root } \\
\text { vegetables, eggs, and nuts, while } \\
\text { excluding dairy products, cereal } \\
\text { grains, beans, refined fats, sugar, } \\
\text { sweets, soft drinks, beer, and extra } \\
\text { addition of salt. } \\
\text { Diabetes diet, meals with increased } \\
\text { intake of vegetables, root vegetables, } \\
\text { wholegrain bread and other } \\
\text { wholegrain cereal products, fruits, } \\
\text { and berries, and decreased intake of } \\
\text { total fat with more unsaturated fat. }\end{array}$ & $1581 \pm 295^{c, d}$ & 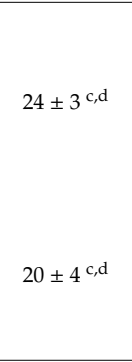 & $39 \pm 5^{c, d}$ & 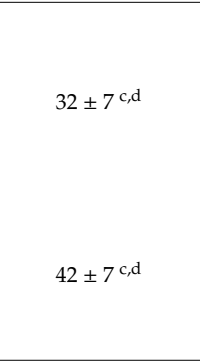 & 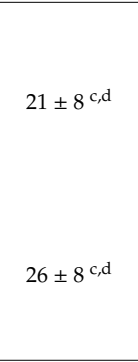 & No \\
\hline Lindeberg et al. [17] & 2007 & $\begin{array}{c}\mathrm{RCT}, \\
\text { parallel }\end{array}$ & 12 & $\begin{array}{l}\text { Control } \\
\text { group }\end{array}$ & 15 & $\begin{array}{l}\text { Based on lean meat, fish, fruits, leafy } \\
\text { and cruciferous vegetables, root } \\
\text { vegetables (including restricted } \\
\text { potatoes), eggs, and nuts. } \\
\text { Consensus (Mediterranean diet) diet } \\
\text { based on wholegrain cereals, low-fat } \\
\text { dairy products, potatoes, legumes, } \\
\text { vegetables, fruits, fatty fish, and } \\
\text { refined fats rich in monounsaturated } \\
\text { fatty acids and alpha-linolenic acid. }\end{array}$ & $1795 \pm 306^{c}$ & $27.9 \pm 6.8^{\mathrm{v}}$ & $\underset{c}{26.9 \pm 6.4}$ & $40.2 \pm 8.3^{c}$ & $21.4 \pm 13.2^{c}$ & No \\
\hline
\end{tabular}


Table 1. Cont.

\begin{tabular}{|c|c|c|c|c|c|c|c|c|c|c|c|c|}
\hline Study & Year & $\begin{array}{l}\text { Type of } \\
\text { Study }\end{array}$ & $\begin{array}{l}\text { Duration of } \\
\text { Intervention } \\
\text { (week) }\end{array}$ & Groups & Subjects $(n)^{\mathrm{a}}$ & Description & Energy (kcal) & Protein (\%) & Fat $(\%)$ & Carbohydrate (\%) & Fiber (g) & $\begin{array}{c}\text { Meals } \\
\text { Supplied by } \\
\text { Researchers }\end{array}$ \\
\hline Masharani et al. [18] & 2015 & $\begin{array}{c}\mathrm{RCT} \text {, } \\
\text { parallel }\end{array}$ & 3 & 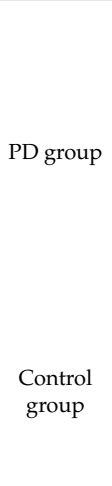 & 10 & $\begin{array}{l}\text { The Paleolithic diet consisted of meat, } \\
\text { fish, poultry, eggs, fruit, vegetables, } \\
\text { tree nuts, canola oil, mayonnaise, } \\
\text { and honey. Excluded dairy products, } \\
\text { legumes, cereals, grains, potatoes, } \\
\text { and products containing potassium } \\
\text { chloride. A series of ramp diets (with } \\
\text { increasing levels of potassium and } \\
\text { fiber) were developed. Ramp } 1 \text { diet } \\
\text { was } 1 \text { day, ramp } 2 \text { for } 3 \text { days, and } \\
\text { ramp } 3 \text { for } 3 \text { days. } \\
\text { Non-Paleolithic-type diet consisting } \\
\text { of cereal grains, dairy, or legumes, } \\
\text { moderate salt intake, low-fat dairy, } \\
\text { whole grains, and legumes; no ramp } \\
\text { up for the American Diabetes } \\
\text { Association (ADA) diet. Diet based on } \\
\text { recommendations by the ADA. }\end{array}$ & N/A & N/A & N/A & N/A & N/A & Yes \\
\hline
\end{tabular}




\subsection{Characteristics of Study Participants}

The characteristics of the study participants are shown in Table 2. In total, 98 subjects were included in the meta-analysis. All studies were conducted in adult populations $[9,13,16-18]$. The average age of study participants ranged from $52.0 \pm 10.2$ years [13] to $66.0 \pm 6.0$ years $[9,16]$ in the Paleolithic diet group, and similar values were observed in the control group. Two studies were conducted in Sweden $[9,16,17]$, one in the Netherlands [13], and one in the United States of America (USA) [18]. One study included only men [17], and three studies included both men and women $[9,13,16]$. In one study, the information about the sex of study participants was not indicated [18]. The mean value of BMI ranged between $28.0 \pm 4.0 \mathrm{~kg} / \mathrm{m}^{2}[9,16]$ and $33.7 \pm 5.9 \mathrm{~kg} / \mathrm{m}^{2}$ [13]. Most of the studies were conducted in Caucasian populations (89\% of total study participants) $[9,13,16-18]$, but Asian (5\% of total study participants) $[13,18]$, African American (3\% of total study participants), and Hispanic subjects (5\% of total study participants) [18] were also included. Two studies included subjects with type 2 diabetes mellitus $[9,16,18]$, one study recruited subjects with ischemic heart disease plus either glucose intolerance or type 2 diabetes [17], and one study was conducted in subjects with at least two characteristics of the metabolic syndrome (of which $78 \%$ of subjects in the Paleolithic group and $44 \%$ of subjects in the control group had fasting glucose levels $\geq 5.6 \mathrm{mmol} / \mathrm{L}$ ) [13].

\subsection{The Effect of the Paleolithic Diet on Fasting Glucose Levels}

The effect of the Paleolithic diet on glucose levels was analyzed in four studies included in this meta-analysis $[9,13,17,18]$. The average baseline blood glucose concentrations ranged from 6.1 $\pm 0.8 \mathrm{mmol} / \mathrm{L}$ [13] to $8.4 \pm 4.2 \mathrm{mmol} / \mathrm{L} \mathrm{[18]} \mathrm{in} \mathrm{the} \mathrm{Paleolithic} \mathrm{group} \mathrm{and} \mathrm{were} \mathrm{similar} \mathrm{to} \mathrm{the} \mathrm{values}$ observed in the control group. Following the intervention period, the mean glucose concentrations decreased in both groups in all studies $[9,13,17,18]$. However, the results were statistically significant only in one study for the Paleolithic group [17] (Table 3). On the other hand, three studies noted significant differences between post-intervention fasting glucose levels in the Paleolithic and the control groups $[9,17,18]$. Nevertheless, this meta-analysis did not report a significant difference between the effect of the Paleolithic diet and the control diet on glucose concentrations (random-effects model, SMD: $-0.343,95 \%$ CI: $-0.867,0.181, p=0.200$, Figure 2 ) and indicated a moderate risk of heterogeneity among the included studies (Q-value $=4.828, p=0.185, \mathrm{I}^{2}=37.857 \%$ ).

\subsection{The Effect of the Paleolithic Diet on Fasting Insulin Levels}

The effect of the Paleolithic diet on insulin concentrations was evaluated in three studies included in this meta-analysis $[9,13,16,17]$. At baseline, in the Paleolithic group, the mean fasting insulin concentrations ranged from $82.64 \pm 38.19 \mathrm{pmol} / \mathrm{L}[13]$ to $118.00 \pm 53.00 \mathrm{pmol} / \mathrm{L}[9,16]$. After the intervention, the mean fasting insulin levels decreased in both groups in all studies [9,13,16,17]; however, there were significant differences between pre- and post-intervention insulin levels in only two studies in the Paleolithic group $[9,16,17]$ (Table 3). However, the results of this meta-analysis showed no significant differences between the effect of the Paleolithic diet and the control diets on insulin levels (fixed-effects model, SMD: $-0.141,95 \%$ CI: $-0.599,0.318, p=0.548$, Figure 3 ). In addition, we observed a very low and insignificant risk of heterogeneity among the included studies (Q-value $=0.459, p=0.795, \mathrm{I}^{2}=0.000 \%$ ).

\subsection{The Effect of the Paleolithic Diet on HOMA-IR}

The effect of the Paleolithic diet on the HOMA-IR index was analyzed in three selected studies $[9,13,17]$. At baseline, in two studies, the mean values of the HOMA-IR index were equal or exceeded a value of 1.8 , indicating insulin resistance $[9,13]$. In all studies, the values of the HOMA-IR index decreased after the intervention period $[9,13,17]$; however, the results were significant in only two studies in the Paleolithic diet group $[9,17]$ and in one study in the control group $[9,17]$ (Table 3). In addition, the results from the meta-analysis did not show any significant differences between the effect of the Paleolithic diet and the control diets on HOMA-IR index (fixed-effects model, SMD: -0.151, 
$95 \%$ CI: $-0.610,0.309, p=0.521$, Figure 4$)$, with low to no significant heterogeneity among the included studies (Q-value $=0.645, p=0.724, \mathrm{I}^{2}=0.000 \%$ ).

\subsection{The Effect of the Paleolithic Diet on HbA1c Values}

The effect of the Paleolithic diet on HbA1c values was assessed in three studies $[9,17,18]$. At baseline, mean $\mathrm{HbA1c}$ values in the Paleolithic group ranged from $4.76 \pm 0.26 \%$ [17] to $7.30 \pm 2.10 \%$ [18]. A significant decrease in the $\mathrm{HbA1c}$ values was noted after the intervention period in two studies in both the Paleolithic group and the control group $[9,18]$. However, the meta-analysis did not confirm significant differences between the effect of the Paleolithic diet and other types of diets on $\mathrm{HbA1c}$ values (fixed-effects model, SMD: $-0.380,95 \% \mathrm{CI}:-0.870,0.110, p=0.129$, Figure 5 ) and indicated a low risk of heterogeneity ( $\mathrm{Q}$-value $=0.104, p=0.949, \mathrm{I}^{2}=0.000 \%$ ).

$\mathrm{HbA} 1 \mathrm{c}$ values provide information about average glucose concentrations over the past three months. Therefore, it was suggested that this marker is not reliable in studies with an intervention period shorter than three months [31]. In this meta-analysis, we performed a separate analysis for studies with an intervention period of at least 12 weeks. Nevertheless, the results of this analysis showed no significant differences between the effect of the Paleolithic diet and control diets on $\mathrm{HbA1c}$ values (fixed-effects model, SMD: $-0.434,95 \% \mathrm{CI}:-1.047,0.179, p=0.165$, Figure 6 ) and indicated a low risk of heterogeneity ( $\mathrm{Q}$-value $=0.021, p=0.885, \mathrm{I}^{2}=0.000 \%$ ).

\subsection{The Effect of the Paleolithic Diet on AUC 0-120 Glucose Levels}

The effect of the Paleolithic diet on AUC 0-120 glucose levels was analyzed in three studies $[9,13,17]$. At baseline, the mean AUC 0-120 glucose levels in the intervention groups ranged from $263 \pm 208 \mathrm{mmol} / \mathrm{L}$ $\times \min [13]$ to $1498 \pm 227 \mathrm{mmol} / \mathrm{L} \times \min [9]$. After the intervention period, the AUC 0-120 glucose levels decreased in all studies $[9,13,17]$. However, the results were significant only in the Paleolithic diet in two studies $[9,17]$ (Table 4). However, our meta-analysis showed no significant differences between the effect of the Paleolithic diet and the control diets on AUC 0-120 glucose levels (random-effects model, SMD: $-0.558 ; 95 \%$ CI: $-1.380,0.264 ; p=0.183$, Figure 7 ) and indicated a moderate risk of heterogeneity (Q-value $\left.=5.598, p=0.061, \mathrm{I}^{2}=64.271 \%\right)$. 
Table 2. Characteristics of the included studies and the study populations.

\begin{tabular}{|c|c|c|c|c|c|c|c|c|c|}
\hline \multirow[t]{2}{*}{ Study } & \multirow[t]{2}{*}{ Country } & \multirow{2}{*}{$\begin{array}{c}\text { Analysed } \\
\text { Groups }\end{array}$} & \multirow{2}{*}{$\begin{array}{l}\text { Age (years) } \\
\text { Mean } \pm S D\end{array}$} & \multirow{2}{*}{$\begin{array}{l}\text { Sex (\% of } \\
\text { Women) }\end{array}$} & \multirow{2}{*}{$\begin{array}{l}\text { BMI }\left(\mathrm{kg} / \mathrm{m}^{2}\right) \\
\text { Mean } \pm \mathrm{SD}\end{array}$} & \multicolumn{2}{|c|}{$\begin{array}{l}\text { Body Weight (kg) } \\
\text { Mean } \pm \text { SD }\end{array}$} & \multirow[t]{2}{*}{ Race/Ethnicity (\%) } & \multirow[t]{2}{*}{ Health Status } \\
\hline & & & & & & Preintervention & Postinterventior & & \\
\hline \multirow[b]{2}{*}{ Boers et al. [13] } & \multirow[b]{2}{*}{ The Netherlands } & PD group & $52.0 \pm 10.2$ & $72 \%$ & $33.7 \pm 5.9$ & $98.0 \pm 18.2^{*}$ & $95.3 \pm 17.5^{*}$ & Caucasian 100\% & \multirow{2}{*}{ 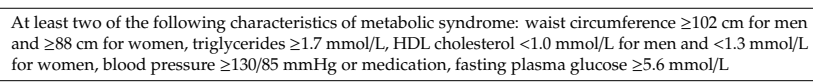 } \\
\hline & & $\begin{array}{l}\text { Control } \\
\text { group }\end{array}$ & $55.4 \pm 9.0$ & $75 \%$ & $29.8 \pm 4.9$ & $86.0 \pm 14.2$ & $84.3 \pm 12.5$ & Caucasian $87.5 \%$, Asian $12.5 \%$ & \\
\hline Fontes-Villalba et al. $[16]^{\mathrm{a}}$ & \multirow[b]{2}{*}{ Sweden } & PD group & $66.0 \pm 6.0$ & $14 \%$ & $28.0 \pm 4.0$ & $92.0 \pm 20.0$ & $81.0 \pm 13.0$ *\#\# & \multirow[b]{2}{*}{ Caucasian 100\% } & \multirow{2}{*}{ Subjects with type 2 diabetes without insulin treatment } \\
\hline Jönsson et al. [9] ${ }^{a}$ & & $\begin{array}{l}\text { Control } \\
\text { group }\end{array}$ & $63.0 \pm 6.0$ & $33 \%$ & $32.0 \pm 8.0$ & $82.0 \pm 13.0$ & $84.0 \pm 15.0^{\#}$ & & \\
\hline Lindeberg et al. [17] & Sweden & $\begin{array}{l}\text { PD group } \\
\text { Control } \\
\text { group }\end{array}$ & $\begin{array}{l}65.0 \pm 10.0 \\
57.0 \pm 7.0\end{array}$ & $0 \%$ & $\begin{array}{l}29.0 \pm 4.0 \\
30.0 \pm 2.0\end{array}$ & $\begin{array}{l}91.7 \pm 11.2 \\
96.1 \pm 12.4\end{array}$ & $\begin{array}{l}88.0 \pm 10.7^{\#} \\
93.5 \pm 12.8^{\#}\end{array}$ & Caucasian $100 \%$ & Subjects with ischemic heart disease plus either glucose intolerance or type 2 diabetes \\
\hline Masharani et al. [18] & USA & $\begin{array}{l}\text { PD group } \\
\text { Control } \\
\text { group }\end{array}$ & $\begin{array}{l}58.0 \pm 8.0 \\
56.0 \pm 13.0\end{array}$ & N/A & $\begin{array}{l}31.0 \pm 5.0 \\
34.0 \pm 7.0\end{array}$ & N/A & $\begin{array}{l}-2.4 \pm 0.7^{\mathrm{b}, \mathrm{t}} \\
-2.1 \pm 1.9^{\mathrm{b}, \mathrm{A}}\end{array}$ & $\begin{array}{l}\text { Caucasian } 62.5 \% \text {, African American } 12.5 \% \text {, } \\
\text { Asian 12.5\%, Hispanic 12.5\% }\end{array}$ & Subjects with type 2 diabetes \\
\hline
\end{tabular}

${ }^{a}$ Studies conducted on the same population. ${ }^{\mathrm{b}}$ Delta (value at the end of the intervention period minus value at baseline). BMI—body mass index; HDL—high-density lipoprotein; N/A—not available; PD—Paleolithic diet; USA-United States of America. ${ }^{*}$ Significant difference between PD group and control group; ${ }^{\#}$ significant difference between pre-intervention and post-intervention.

Table 3. Effect of the Paleolithic diet on fasting glucose and insulin levels, HbA1c, and HOMA-IR (mean $\pm \mathrm{SD}$ ).

\begin{tabular}{|c|c|c|c|c|c|c|c|c|c|}
\hline \multirow{2}{*}{ Study } & \multirow{2}{*}{$\begin{array}{c}\text { Analyzed } \\
\text { Groups }\end{array}$} & \multicolumn{2}{|c|}{ Fasting Glucose $(\mathrm{mmol} / \mathrm{L})$} & \multicolumn{2}{|c|}{ Fasting Insulin (pmol/L) } & \multicolumn{2}{|c|}{ HOMA-IR } & \multicolumn{2}{|c|}{ HbA1c (\%) } \\
\hline & & Pre-Intervention & Post-Intervention & Pre-Intervention & Post-Intervention & Pre-Intervention & Post-Intervention & Pre-Intervention & Post-Intervention \\
\hline Boers et al. [13] & $\begin{array}{l}\text { PD group } \\
\text { Control group }\end{array}$ & $\begin{array}{l}6.1 \pm 0.8 \\
5.8 \pm 0.7\end{array}$ & $\begin{array}{l}5.7 \pm 0.8 \\
5.5 \pm 0.8\end{array}$ & $\begin{array}{l}82.64 \pm 38.19 \\
70.83 \pm 45.14\end{array}$ & $\begin{array}{l}63.89 \pm 34.03 \\
65.97 \pm 36.80\end{array}$ & $\begin{array}{l}3.30 \pm 1.70 \\
2.70 \pm 1.80\end{array}$ & $\begin{array}{l}2.40 \pm 1.60 \\
2.40 \pm 1.30\end{array}$ & \multicolumn{2}{|c|}{$\mathrm{N} / \mathrm{A}$} \\
\hline Fontes-Villalba et al. [16] ${ }^{\mathrm{a}}$ & $\begin{array}{l}\text { PD group } \\
\text { Control group }\end{array}$ & \multicolumn{2}{|c|}{ N/A } & $\begin{array}{c}118.00 \pm 53.00 * \\
75.00 \pm 12.00\end{array}$ & $\begin{array}{c}69.00 \pm 30.00^{\#} \\
67.00 \pm 20.00\end{array}$ & \multicolumn{2}{|c|}{$\mathrm{N} / \mathrm{A}$} & \multicolumn{2}{|c|}{$\mathrm{N} / \mathrm{A}$} \\
\hline Jönsson et al. [9] ${ }^{\text {a }}$ & $\begin{array}{l}\text { PD group } \\
\text { Control group }\end{array}$ & $\begin{array}{c}7.1 \pm 0.7^{*} \\
8.6 \pm 1.2\end{array}$ & $\begin{array}{c}7.0 \pm 1.4^{*} \\
7.5 \pm 1.4\end{array}$ & $\begin{array}{c}118.00 \pm 53.00 * \\
75.00 \pm 12.00\end{array}$ & $\begin{array}{c}69.00 \pm 30.00 \text { \# } \\
67.00 \pm 20.00\end{array}$ & $\begin{array}{l}2.40 \pm 1.00 \\
1.60 \pm 0.30\end{array}$ & $\begin{array}{c}1.40 \pm 0.60^{\#} \\
1.40 \pm 0.40\end{array}$ & $\begin{array}{l}6.20 \pm 0.20 \\
6.90 \pm 0.70\end{array}$ & $\begin{array}{c}5.50 \pm 0.70 \text { *\# } \\
5.90 \pm 0.90^{\text {\# }}\end{array}$ \\
\hline \multirow{2}{*}{ Lindeberg et al. [17] } & $\begin{array}{l}\text { PD group }{ }^{b} \\
\text { PD group }^{c}\end{array}$ & $6.8 \pm 1.3$ & $\begin{array}{c}5.2 \pm 1.1 \\
5.1 \pm 1.0^{*} \text {,\# }\end{array}$ & $102.00 \pm 36.00$ & $\begin{array}{c}91.00 \pm 32.00 \\
86.00 \pm 36.00 \#\end{array}$ & $0.62 \pm 0.38$ & $\begin{array}{c}0.47 \pm 0.33 \\
0.39 \pm 0.36^{\#}\end{array}$ & $4.76 \pm 0.26$ & $\begin{array}{l}4.61 \pm 0.25 \\
4.64 \pm 0.22\end{array}$ \\
\hline & $\begin{array}{l}\text { Control group }{ }^{b} \\
\text { Control group }{ }^{c}\end{array}$ & $7.1 \pm 1.8$ & $\begin{array}{l}5.8 \pm 1.2 \\
6.2 \pm 1.4\end{array}$ & $123.00 \pm 68.00$ & $\begin{array}{l}100.00 \pm 45.00 \\
101.00 \pm 53.00\end{array}$ & $0.75 \pm 0.53$ & $\begin{array}{c}0.55 \pm 0.42 \\
0.55 \pm 0.46^{\#}\end{array}$ & $4.89 \pm 0.79$ & $\begin{array}{l}4.84 \pm 0.72 \\
4.85 \pm 0.69\end{array}$ \\
\hline Masharani et al. [18] & $\begin{array}{l}\text { PD group } \\
\text { Control group }\end{array}$ & $\begin{array}{l}8.4 \pm 4.2 \\
7.7 \pm 2.5\end{array}$ & $\begin{array}{c}-1.3 \pm 1.4^{\mathrm{d}, *} \\
0.6 \pm 1.8^{\mathrm{d}}\end{array}$ & \multicolumn{2}{|c|}{ N/A } & \multicolumn{2}{|c|}{$\mathrm{N} / \mathrm{A}$} & $\begin{array}{l}7.30 \pm 2.10 \\
7.00 \pm 1.50\end{array}$ & $\begin{array}{l}-0.30 \pm 0.49^{\mathrm{d}, \#} \\
-0.18 \pm 0.24 \mathrm{~d}, \#\end{array}$ \\
\hline
\end{tabular}

a Studies conducted on the same population. ${ }^{\mathrm{b}}$ Data after six weeks. ${ }^{\mathrm{c}}$ Data after 12 weeks. ${ }^{\mathrm{d}}$ Delta (value at the end of the intervention period minus value at the baseline. ${ }^{*}$ Significant difference between PD group and control group; ${ }^{\#}$ significant difference between pre-intervention and post-intervention. HbA1c—glycated hemoglobin; HOMA-IR—homeostasis model assessment of insulin resistance; N/A—not available; PD—Paleolithic diet. 


\begin{tabular}{|c|c|c|c|c|c|c|c|c|c|c|}
\hline \multirow[t]{2}{*}{ Study name } & \multicolumn{2}{|c|}{ Time point } & \multicolumn{4}{|c|}{ Statistics for each study } & & & \multicolumn{2}{|c|}{ Sample size } \\
\hline & & $\begin{array}{l}\text { Std diff } \\
\text { in means }\end{array}$ & $\begin{array}{l}\text { Standard } \\
\text { error }\end{array}$ & Variance & $\begin{array}{l}\text { Lower } \\
\text { limit }\end{array}$ & Upper & Z-Value & p-Value & Paleolit| & Control \\
\hline Boers I. et al. & 2 & 0.250 & 0.358 & 0.128 & -0.451 & 0.951 & 0.699 & 0.485 & 18 & 14 \\
\hline Jönsson T. et al. & 12 & -0.357 & 0.561 & 0.314 & -1.456 & 0.742 & -0.637 & 0.524 & 7 & 6 \\
\hline Lindeberg S. et al. 1 & 12 & -0.899 & 0.390 & 0.152 & -1.663 & -0.135 & -2.305 & 0.021 & 14 & 15 \\
\hline Masharani U. et al. & & -0.439 & 0.419 & 0.175 & -1.260 & 0.381 & -1.049 & 0.294 & 14 & 10 \\
\hline & & -0.343 & 0.267 & 0.071 & -0.867 & 0.181 & -1.282 & 0.200 & & \\
\hline
\end{tabular}

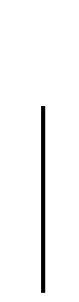

$-2.00$

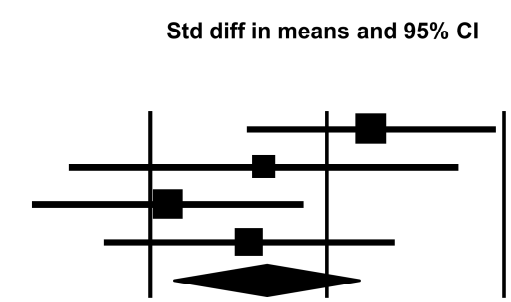

$-1.00$
0.00

1.00
Relative
weight

16.93

27.51

25.24

Favours A

Favours B

Figure 2. Forest plot comparing fasting glucose levels between the diets (favors A-Paleo group; favors B-control group).

\section{Study name}

Time point

Statistics for each study

Sample size

Std diff in means and $95 \% \mathrm{Cl}$

\section{in means error Variance limit limit Z-Value p-Value Paleolithic Contro}

Boers I. et al.

Jönsson T. et al. 12

$\begin{array}{lllllllll}-0.059 & 0.356 & 0.127 & -0.758 & 0.640 & -0.166 & 0.869 & 18 & 14\end{array}$

Lindeberg S. et al. 12

$\begin{array}{lllllll}0.077 & 0.557 & 0.310 & -1.014 & 1.168 & 0.139 & 0.890\end{array}$

$\begin{array}{lllllll}-0.329 & 0.374 & 0.140 & -1.062 & 0.404 & -0.879 & 0.379\end{array}$

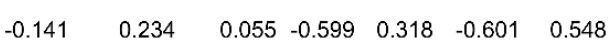

$\begin{array}{cc}18 & 14 \\ 7 & 6 \\ 14 & 15\end{array}$

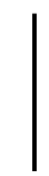

$-2.00$

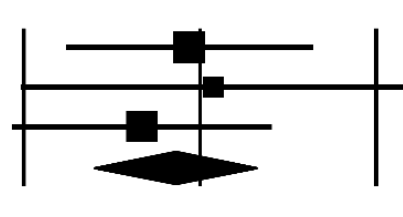

$-1.00$
0.00
Relative
weight

43.14

17.69

39.16

\section{Favours A}

Favours B

Figure 3. Forest plot comparing fasting insulin levels between the diets (favors A-Paleo group; favors B-control group). 


\begin{tabular}{|c|c|c|c|c|c|c|c|c|c|c|}
\hline \multirow[t]{2}{*}{ Study name } & \multirow{2}{*}{ Time poin } & \multicolumn{5}{|c|}{ Statistics for each study } & & & \multicolumn{2}{|c|}{ Sample size } \\
\hline & & $\begin{array}{l}\text { Std diff } \\
\text { in means }\end{array}$ & $\begin{array}{l}\text { Standard } \\
\text { error }\end{array}$ & Variance & $\begin{array}{l}\text { Lower } \\
\text { limit }\end{array}$ & $\begin{array}{c}\text { Upper } \\
\text { limit }\end{array}$ & Z-Value & p-Value & aleolit & Control \\
\hline Boers I. et al. & 2 & 0.000 & 0.356 & 0.127 & -0.698 & 0.698 & 0.000 & 1.000 & 18 & 14 \\
\hline Jönsson T. et al. & 12 & 0.000 & 0.556 & 0.310 & -1.090 & 1.090 & 0.000 & 1.000 & 7 & 6 \\
\hline \multirow[t]{2}{*}{ Lindeberg S. et al. } & & -0.386 & 0.375 & 0.141 & -1.121 & 0.349 & -1.028 & 0.304 & 14 & 15 \\
\hline & & -0.151 & 0.234 & 0.055 & -0.610 & 0.309 & -0.642 & 0.521 & & \\
\hline
\end{tabular}

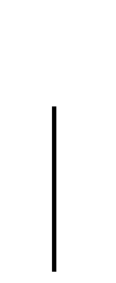

$-2.00$
Std diff in means and $95 \% \mathrm{Cl}$

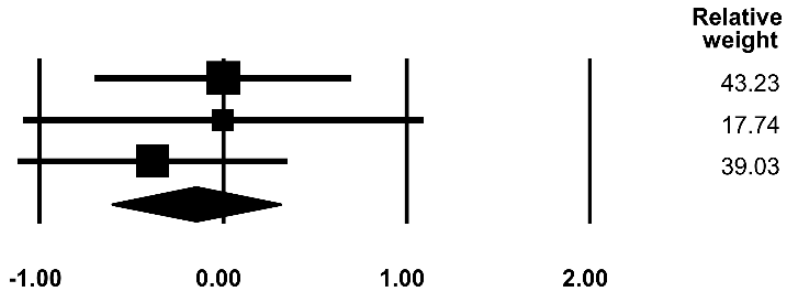

$\begin{array}{ll}\text { Favours A } & \text { Favours B }\end{array}$

Figure 4. Forest plot comparing homeostasis model assessment of insulin resistance (HOMA-IR) between the diets (favors A—Paleo group; favors B-control group).

\begin{tabular}{|c|c|c|c|c|c|c|c|c|c|c|}
\hline \multirow[t]{2}{*}{ Study name } & \multicolumn{2}{|l|}{ Time point } & \multicolumn{4}{|c|}{ Statistics for each study } & & & \multicolumn{2}{|c|}{ Sample size } \\
\hline & & $\begin{array}{l}\text { Std diff } \\
\text { in means }\end{array}$ & $\begin{array}{l}\text { Standard } \\
\text { error }\end{array}$ & Variance & $\begin{array}{l}\text { Lower } \\
\text { e limit }\end{array}$ & Upper & Z-Value & p-Value & Paleoli & Contro \\
\hline Jönsson T. et al. & 12 & -0.502 & 0.565 & 0.319 & -1.609 & 0.606 & -0.888 & 0.374 & 7 & 6 \\
\hline Lindeberg S. et al. & 12 & -0.404 & 0.375 & 0.141 & -1.140 & 0.332 & -1.076 & 0.282 & 14 & 15 \\
\hline Masharani U. et al. & & -0.284 & 0.416 & 0.173 & -1.099 & 0.532 & -0.682 & 0.495 & 14 & 10 \\
\hline & & -0.380 & 0.250 & 0.062 & -0.870 & 0.110 & -1.520 & 0.129 & & \\
\hline
\end{tabular}

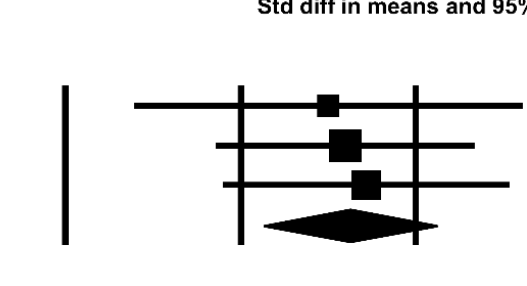

$-2.00$
$-1.00$
Std diff in means and $95 \% \mathrm{Cl}$

0.00
Relative
weight

19.57
44.34

36.09

Favours A

Favours B

Figure 5. Forest plot comparing glycated hemoglobin (HbA1c) values between the diets (favors A—Paleo group; favors B—control group). 
Study name

Time point

Statistics for each study

Sample size

Std diff in means and $95 \% \mathrm{Cl}$

Std diff Standard
in means error Variance limit limit Z-Value p-Value Paleolithic Control

$\begin{array}{lllllllllll}\text { Jönsson T. et al. } 12 & -0.502 & 0.565 & 0.319 & -1.609 & 0.606 & -0.888 & 0.374 & 7 & 6\end{array}$

$\begin{array}{llllllllll}\text { Lindeberg S. et al. } 12 & -0.404 & 0.375 & 0.141 & -1.140 & 0.332 & -1.076 & 0.282 & 14 & 15\end{array}$

$\begin{array}{llllllll}-0.434 & 0.313 & 0.098 & -1.047 & 0.179 & -1.388 & 0.165\end{array}$

6
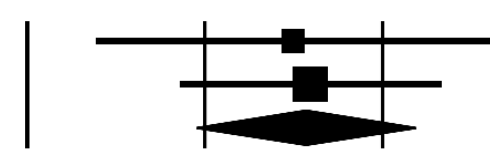

weight

30.62

69.38

$-2.00$

$-1.00$

0.00

1.00

.00

$\begin{array}{ll}\text { Favours A } & \text { Favours B }\end{array}$

Figure 6. Forest plot comparing HbA1c values between the diets in studies with an intervention period of at least 12 weeks (favors A—Paleo group; favors B-control group).

\begin{tabular}{|c|c|c|c|c|c|c|c|c|c|c|}
\hline \multirow[t]{2}{*}{ Study name } & \multicolumn{2}{|c|}{ Time point } & \multicolumn{4}{|c|}{ Statistics for each study } & & & \multicolumn{2}{|c|}{ Sample size } \\
\hline & & $\begin{array}{l}\text { Std diff } \\
\text { in means }\end{array}$ & $\begin{array}{l}\text { Standard } \\
\text { error }\end{array}$ & Variance & e $\begin{array}{l}\text { Lower } \\
\text { limit }\end{array}$ & $\begin{array}{c}\text { Upper } \\
\text { limit }\end{array}$ & & & alaeolit & \\
\hline Boers I. et al. & 2 & -0.082 & 0.356 & 0.127 & -0.781 & 0.616 & -0.231 & 0.817 & 18 & 14 \\
\hline Jönsson T. et al. & 12 & -0.239 & 0.558 & 0.312 & -1.333 & 0.855 & -0.428 & 0.669 & 7 & 6 \\
\hline Lindeberg S. et al & & -1.325 & 0.410 & 0.168 & -2.129 & -0.521 & -3.229 & 0.001 & 14 & 15 \\
\hline & & -0.558 & 0.419 & 0.176 & -1.380 & 0.264 & -1.331 & 0.183 & & \\
\hline
\end{tabular}

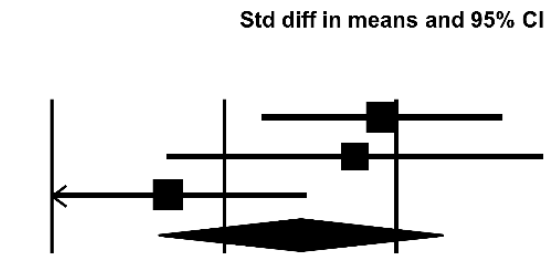

$-2.00$

$-1.00$

0.00

1.00

2.00

Favours A

Favours B

Figure 7. Forest plot comparing area under the curve (AUC) 0-120 glucose levels between the diets (favors A—Paleo group; favors B-control group). 
Table 4. Effect of the Paleolithic diet on AUC 0-120 glucose and AUC 0-120 insulin (mean \pm SD).

\begin{tabular}{|c|c|c|c|c|c|c|}
\hline \multirow[t]{2}{*}{ Study } & \multirow[t]{2}{*}{ Year } & \multirow[t]{2}{*}{ Analyzed Groups } & \multicolumn{2}{|c|}{$\begin{array}{c}\text { AUC 0-120 Glucose } \\
(\mathrm{mmol} / \mathrm{L} \times \mathrm{min})\end{array}$} & \multicolumn{2}{|c|}{$\begin{array}{c}\text { AUC 0-120 Insulin } \\
(\text { pmol/L } \times \text { min })\end{array}$} \\
\hline & & & Pre-Intervention & Post-Intervention & Pre-Intervention & Post-Intervention \\
\hline \multirow{2}{*}{ Boers et al. [13] } & \multirow{2}{*}{2014} & PD group & $263 \pm 208$ & $245 \pm 199$ & $61,047 \pm 43,056$ & $47,729 \pm 18,694$ \\
\hline & & Control group & $249 \pm 162$ & $262 \pm 216$ & $43,542 \pm 25,132$ & $48,299 \pm 23,368$ \\
\hline \multirow{2}{*}{ Jönsson et al. [9] } & \multirow{2}{*}{2009} & PD group & $1498 \pm 227$ & $1398 \pm 314^{\#}$ & $35,000 \pm 13,000$ & $26,000 \pm 14,000$ \\
\hline & & Control group & $1734 \pm 128$ & $1478 \pm 358$ & $24,000 \pm 8000$ & $27,000 \pm 13,000$ \\
\hline \multirow[b]{2}{*}{ Lindeberg et al. [17] } & \multirow[b]{2}{*}{2007} & $\begin{array}{l}\text { PD group }{ }^{a} \\
\text { PD group }\end{array}$ & $1104 \pm 118$ & $\begin{array}{c}877 \pm 161^{\#} \\
807 \pm 107^{*, \#}\end{array}$ & $80,500 \pm 41,100$ & $\begin{array}{l}63,100 \pm 30,000^{\#} \\
56,100 \pm 30,100^{\#}\end{array}$ \\
\hline & & $\begin{array}{l}\text { Control group }{ }^{\mathrm{a}} \\
\text { Control group }^{\mathrm{b}}\end{array}$ & $1145 \pm 298$ & $\begin{array}{l}1024 \pm 339 \\
1065 \pm 250\end{array}$ & $69,700 \pm 44,700$ & $\begin{array}{c}54,100 \pm 37,200^{\#} \\
60,400 \pm 46,400\end{array}$ \\
\hline
\end{tabular}

${ }^{a}$ Data after six weeks. ${ }^{b}$ Data after 12 weeks. * Significant difference between PD group and control group;

\# significant difference between pre-intervention and post-intervention. AUC-area under the curve; N/A-not

available; PD—Paleolithic diet.

\subsection{The Effect of the Paleolithic Diet on AUC 0-120 Insulin Levels}

Three studies analyzed the effect of the Paleolithic diet on AUC 0-120 insulin levels $[9,13,17]$. The baseline average AUC 0-120 insulin concentrations in the Paleolithic diet were in the range of $35,000 \pm 13,000 \mathrm{pmol} / \mathrm{L} \times \min [9]$ to $80,500 \pm 41,100 \mathrm{pmol} / \mathrm{L} \times \min$ [17]. After the intervention period in the Paleolithic group, AUC 0-120 insulin levels decreased in all included studies $[9,13,17]$. However, the results were significant in only one study both in the Paleolithic group and in the control group [17]. Our meta-analysis showed no differences in the effect between diets on AUC 0-120 insulin levels (fixed-effects model, SMD: $-0.068,95 \%$ CI: $-0.526,0.390, p=0.772$, Figure 8 ) and noted a low risk of heterogeneity among the included studies ( $\mathrm{Q}$-value $=0.025, p=0.987, \mathrm{I}^{2}=0.000 \%$ ).

\subsection{Risk of Bias}

Risk of bias is presented in Table 5. Because blinding is impossible in dietary intervention studies, the blinding of subjects and researches was not considered. Most of the included studies were classified as a good quality $[9,13,16,17]$. However, one study [18] was of fair quality because it did not report methods of allocation concealment and random sequence generation. 


\begin{tabular}{|c|c|c|c|c|c|c|c|c|c|c|}
\hline \multirow[t]{2}{*}{ Study name } & \multicolumn{2}{|c|}{ Time point } & \multicolumn{4}{|c|}{ Statistics for each study } & & \multicolumn{3}{|c|}{ Sample size } \\
\hline & & $\begin{array}{l}\text { Std diff } \\
\text { in means }\end{array}$ & $\begin{array}{l}\text { Standard } \\
\text { error }\end{array}$ & Varian & $\begin{array}{l}\text { Lower } \\
\text { limit }\end{array}$ & $\begin{array}{l}\text { Upper } \\
\text { limit }\end{array}$ & Z-Value & & aleoli & Control \\
\hline Boers I. et al. & 2 & -0.027 & 0.356 & 0.127 & -0.726 & 0.671 & -0.077 & 0.939 & 18 & 14 \\
\hline Jönsson T. et al. 1 & 12 & -0.074 & 0.557 & 0.310 & -1.165 & 1.017 & -0.133 & 0.895 & 7 & 6 \\
\hline \multirow[t]{2}{*}{ Lindeberg S. et al. } & & -0.109 & 0.372 & 0.138 & -0.838 & 0.620 & -0.293 & 0.769 & 14 & 15 \\
\hline & & -0.068 & 0.234 & 0.055 & -0.526 & 0.390 & -0.290 & 0.772 & & \\
\hline
\end{tabular}

Std diff in means and $95 \% \mathrm{Cl}$

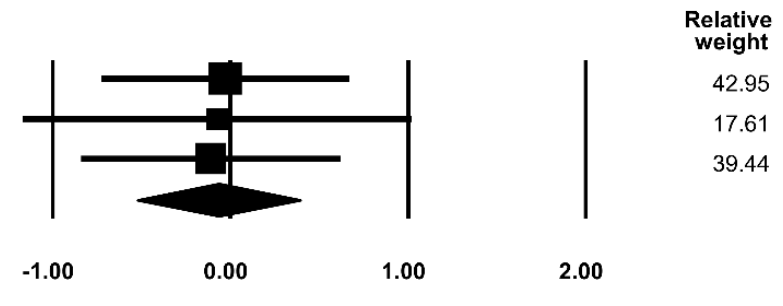

Favours A Favours B

Figure 8. Forest plot comparing AUC 0-120 insulin levels between the diets (favors A-Paleo group; favors B-control group).

Table 5. Risk of bias summary according to the Cochrane risk of bias tool.

\begin{tabular}{|c|c|c|c|c|c|c|c|}
\hline \multirow[b]{2}{*}{ Study } & \multicolumn{2}{|c|}{ Selection Bias } & \multirow{2}{*}{$\begin{array}{c}\text { Performance Bias } \\
\text { Blinding of } \\
\text { Participants and } \\
\text { Personnel }\end{array}$} & \multirow{2}{*}{$\begin{array}{c}\text { Detection Bias } \\
\text { Blinding of } \\
\text { Outcome } \\
\text { Assessment }\end{array}$} & \multirow{2}{*}{$\begin{array}{c}\text { Attrition Bias } \\
\text { Incomplete } \\
\text { Outcome Data } \\
\text { Addressed }\end{array}$} & \multirow{2}{*}{$\begin{array}{c}\text { Reporting Bias } \\
\text { Selective } \\
\text { Reporting }\end{array}$} & \multirow[b]{2}{*}{ Quality } \\
\hline & $\begin{array}{l}\text { Random } \\
\text { Sequence } \\
\text { Generation }\end{array}$ & $\begin{array}{c}\text { Allocation } \\
\text { Concealment }\end{array}$ & & & & & \\
\hline Boers et al. [13] & + & - & - & + & + & + & Good \\
\hline Fontes-Villalba et al. [16] a & + & - & - & + & + & + & Good \\
\hline Jönsson et al. [9] a & + & - & - & + & + & + & Good \\
\hline Lindeberg et al. [17] & + & _- & _- & + & ? & + & Good \\
\hline Masharani et al. [18] & $?$ & - & - & - & + & + & Fair \\
\hline
\end{tabular}

${ }^{\text {a }}$ Studies conducted on the same population; + low risk; ? unclear risk; - high risk. 


\section{Discussion}

The present meta-analysis demonstrates that the Paleolithic diet did not differ from other types of diets commonly perceived as healthy regarding its effect on fasting glucose and insulin concentrations, AUC 0-120 glucose and AUC 0-120 insulin levels, HbA1c values, and the HOMA-IR index.

Despite the fact that, at the end of the intervention period, a decrease in fasting glucose concentrations in the Paleolithic group was observed in most of the studies included in this systematic review $[9,13,17,18]$, our meta-analysis did not show significant differences between the effect of the Paleolithic diet and control diets on fasting glucose levels. Similar results were observed in the previous meta-analysis by Manheimer et al. [8] who also found that the Paleolithic diet did not significantly improve fasting glucose levels. Nevertheless, previous studies showed that a low-carbohydrate diet can contribute to an improvement in fasting glucose levels. In addition, this effect was pronounced in subject with type 2 diabetes [32,33]. Recently, Otten et al. [34] also observed that the Paleolithic diet decreased fasting glucose concentrations in overweight and obese subjects with type 2 diabetes mellitus; however, the authors reported no differences between patients following the Paleolithic diet with standard-care exercise recommendations and the Paleolithic diet together with a 3-h weekly supervised exercise training ( $-17 \%$ vs. $-26 \%$ ). The lack of differences between the effect of the Paleolithic diet and control diets on glucose concentrations observed in this meta-analysis might be partly explained by the negative effect of the Paleolithic diet on microbiota composition. Indeed, it is now well established that an imbalanced gut microbiota is linked to host glycemic control impairment and type 2 diabetes development [35]. In addition, Genoni et al. [36] suggested that long-term adherence to the Paleolithic diet may not be beneficial for gut health, due to the association with lower relative abundances of known beneficial bacterial genera, and the increased relative abundance of trimethylamine- $N$-oxide producing genus Hungatella. This is, however, only a speculation since we did not have access to data relating to the gut microbiome.

The previous meta-analysis conducted by Ghaedi et al. [37] reported that the Paleolithic diet could significantly decrease anthropometric parameters, including body weight, waist circumference, BMI, and fat mass. These results were also confirmed by Manheimer et al. [8], who pointed out that Paleolithic nutrition was more effective in reducing body weight in comparison to the control diet. Previous studies also reported that the Paleolithic diet is more satiating than other types of diets. The composition of the diet is likely to be an important factor in satiety and body weight management. It was suggested that the high protein content of a diet might increase satiety and weight loss [13,38]. Body weight is also an important factor that might affect fasting insulin levels. In fact, body weight reduction is reported to significantly decrease fasting insulin concentrations [39]. Here, we observed that the Paleolithic diet did not affect fasting insulin levels when compared to the control group. It is possible that these results could be explained by similar body weight changes after the intervention period observed in both groups. Indeed, in three studies included in this meta-analysis, body weight significantly decreased in both groups after the intervention period $[9,16-18]$. However, two studies observed significant differences between post-intervention body weight, with lower body weight noted in the Paleolithic group $[9,13,16]$.

It is well known that fasting insulin is associated with insulin resistance, which is an essential factor in developing type 2 diabetes. Furthermore, insulin resistance is also implicated in obesity, hypertension, cancer, or autoimmune diseases [40]. Insulin resistance is also associated with excess fat, obesity, or altered lipid profiles [41]. High fasting insulin levels are related to the greater resistance of tissues to insulin, which is reflected through the HOMA-IR index [28,42]. Several studies revealed that a diet pattern concentrated mainly on meat, fish, eggs, vegetables, fruits, berries, and nuts might be effective for improving predictors of insulin resistance such as the HOMA index [14,17,19,20,43]. In contrast, our meta-analysis did not show a significant effect of the Paleolithic diet on the HOMA-IR index. It should be noted that insulin resistance is dependent on fasting glucose and insulin levels [44]. Therefore, the lack of significant differences between the effect of the Paleolithic diet and the control 
diet on HOMA-IR can easily be explained by the lack of significant changes in fasting glucose and insulin levels $[10,14]$.

$\mathrm{HbA} 1 \mathrm{c}$ is a glucose homeostasis parameter which is widely used to assess the metabolic control of diabetic subjects [2]. It is strongly associated with severe diabetic complications [45] and can also be used as a screening tool for subjects with prediabetes [2]. The potential of the Paleolithic diet for a decrease in $\mathrm{HbA} 1 \mathrm{c}$ values was observed in three studies included in this systematic review $[9,17,18]$. In addition, a recent meta-analysis showed that a low-carbohydrate diet, followed by a Mediterranean diet and the Paleolithic diet, was ranked as the most optimal dietary approach for the reduction of $\mathrm{HbA1c}$ values [46]. Our meta-analysis, however, did not confirm these results. It is possible that the sample size in studies included in this meta-analysis was too small or the intervention period was too short to detect significant differences between groups.

Our meta-analysis did not show any differences between the effect of the Paleolithic diet and the control diet on AUC 0-120 for glucose and insulin. Similar results were recently obtained by Otten et al. [47] in a study conducted in healthy obese women. Otten et al. [47] observed no difference between the effect of the Paleolithic diet and the control diet on AUC 0-120 for glucose and insulin. However, AUC 0-120 for insulin showed a tendency to decline between baseline and 24 months in both intervention groups.

Several limitations should be listed acknowledged this meta-analysis. Firstly, the number of studies included in this systematic review was relatively small, with a limited number of study participants. Secondly, there were many variations between the studies, including the ethnicity of study participants, age, various metabolic stages, methodology, and duration of the intervention period, as well as a different type of diet used by the control group in selected studies. Moreover, we observed differences in macronutrient composition amongst the included studies. Furthermore, in most included studies, there was no information about the training of the persons who performed the dietary education of the study participants $[9,16,17]$. In addition, some of the referred studies at baseline showed a significant difference between groups [9]. These factors could have influenced the findings and could partly explain why the meta-analysis data show no significant differences between the Paleolithic diet and the control diet. It is important to also note that most of the studies included in this meta-analysis were performed in Caucasian subjects with elevated BMI values. Therefore, our findings cannot be generalized to other ethnicities such as Asians, in addition to populations with lower BMI values. Moreover, we were unable to assess the long-term effect of the Paleolithic diet on glucose and insulin homeostasis.

On the other hand, the strength of this research is that it includes details on the characteristics of the study and study population, as well as the measures taken to reduce the influence of bias in the included studies. Moreover, this is the first meta-analysis to comprehensively compare the effect of the Paleolithic diet with other types of healthy diets on glucose and insulin homeostasis in subjects with altered glucose metabolism.

\section{Conclusions}

In conclusion, this study provides evidence that the Paleolithic diet did not differ from other types of diets commonly perceived as healthy, in its effect on glucose and insulin homeostasis in subjects with altered glucose metabolism. Further RCTs with long-term follow-ups should be applied for future investigations into the potential benefits of Paleolithic nutrition in the setting of diabetes or metabolic syndrome.

Supplementary Materials: The following are available online at http://www.mdpi.com/2077-0383/9/2/296/s1.

Author Contributions: M.J., B.K., and A.J. designed the study, searched databases, performed the selection of studies, analyzed the data, and wrote the manuscript. A.G.-M. edited the manuscript. C.S.S. and J.W. designed the study and commented on the manuscript. All authors have read and agreed to the published version of the manuscript. 
Funding: The publication was co-financed within the framework of the Ministry of Science and Higher Education program as "Regional Initiative Excellence" in years 2019-2022, project number 005/RID/2018/19.

Conflicts of Interest: The authors declare no conflicts of interest.

\section{References}

1. International Diabetes Federation. IDF Diabetes Atlas, 8th ed.; International Diabetes Federation: Brussels, Belgium, 2017.

2. American Diabetes Association. Standards of medical care in diabetes-2019. Diabetes Care 2019, 42 (Suppl. 1), S1-S193. [CrossRef] [PubMed]

3. Luger, M.; Holstein, B.; Schindler, K.; Kruschitz, R.; Ludvik, B. Feasibility and efficacy of an isocaloric high-protein vs. standard diet on insulin requirement, body weight and metabolic parameters in patients with type 2 diabetes on insulin therapy. Exp. Clin. Endocrinol. Diabetes 2013, 121, 286-294. [CrossRef] [PubMed]

4. Dong, J.Y.; Zhang, Z.L.; Wang, P.Y.; Qin, L.Q. Effects of high-protein diets on body weight, glycaemic control, blood lipids and blood pressure in type 2 diabetes: Meta-analysis of randomised controlled trials. Br. J. Nutr. 2013, 110, 781-789. [CrossRef] [PubMed]

5. Vega-López, S.; Venn, B.; Slavin, J. Relevance of the glycemic index and glycemic load for body weight, diabetes, and cardiovascular disease. Nutrients 2018, 10, 1361. [CrossRef]

6. Challa, H.J.; Uppaluri, K.R. Paleolithic Diet; 2019. Available online: https://www.ncbi.nlm.nih.gov/books/ NBK482457/ (accessed on 1 September 2019).

7. Raubenheimer, D.; Rothman, J.M.; Pontzer, H.; Simpson, S.J. Macronutrient contributions of insects to the diets of hunter-gatherers: A geometric analysis. J. Hum. Evol. 2014, 71, 70-76. [CrossRef]

8. Manheimer, E.W.; van Zuuren, E.J.; Fedorowicz, Z.; Pijl, H. Paleolithic nutrition for metabolic syndrome: Systematic review and meta-analysis. Am. J. Clin. Nutr. 2015, 102, 922-932. [CrossRef]

9. Jönsson, T.; Granfeldt, Y.; Ahrén, B.; Branell, U.C.; Pålsson, G.; Hansson, A.; Söderström, M.; Lindeberg, S. Beneficial effects of a Paleolithic diet on cardiovascular risk factors in type 2 diabetes: A randomized cross-over pilot study. Cardiovasc. Diabetol. 2009, 8, 35. [CrossRef]

10. Genoni, A.; Lyons-Wall, P.; Lo, J.; Devine, A. Cardiovascular, metabolic effects and dietary composition of ad-libitum Paleolithic vs. Australian Guide to healthy eating diets: A 4-week randomised trial. Nutrients 2016, 8, 314. [CrossRef]

11. Whalen, K.A.; McCullough, M.L.; Flanders, W.D.; Hartman, T.J.; Judd, S.; Bostick, R.M. Paleolithic and Mediterranean diet pattern scores are inversely associated with biomarkers of inflammation and oxidative balance in adults. J. Nutr. 2016, 146, 1217-1226. [CrossRef]

12. Bligh, H.F.J.; Godsland, I.F.; Frost, G.; Hunter, K.J.; Murray, P.; MacAulay, K.; Hyliands, D.; Talbot, D.C.; Casey, J.; Mulder, T.P.; et al. Plant-rich mixed meals based on Palaeolithic diet principles have a dramatic impact on incretin, peptide YY and satiety response, but show little effect on glucose and insulin homeostasis: An acute-effects randomised study. Br. J. Nutr. 2015, 113, 574-584. [CrossRef]

13. Boers, I.; Muskiet, F.A.; Berkelaar, E.; Schut, E.; Penders, R.; Hoenderdos, K.; Wichers, H.J.; Jong, M.C. Favourable effects of consuming a Palaeolithic-type diet on characteristics of the metabolic syndrome: A randomized controlled pilot-study. Lipids Health Dis. 2014, 13, 160. [CrossRef] [PubMed]

14. Chorell, E.; Ryberg, M.; Larsson, C.; Sandberg, S.; Mellberg, C.; Lindahl, B.; Antti, H.; Olsson, T. Plasma metabolomic response to postmenopausal weight loss induced by different diets. Metabolomics 2016, 12, 85. [CrossRef]

15. Boraxbekk, C.J.; Stomby, A.; Ryberg, M.; Lindahl, B.; Larsson, C.; Nyberg, L.; Olsson, T. Diet-induced weight loss alters functional brain responses during an episodic memory task. Obes. Facts 2015, 8, $261-272$. [CrossRef] [PubMed]

16. Fontes-Villalba, M.; Lindeberg, S.; Granfeldt, Y.; Knop, F.K.; Memon, A.A.; Carrera-Bastos, P.; Picazo, Ó.; Chanrai, M.; Sunquist, J.; Sundquist, K.; et al. Palaeolithic diet decreases fasting plasma leptin concentrations more than a diabetes diet in patients with type 2 diabetes: A randomised cross-over trial. Cardiovasc. Diabetol. 2016, 15, 80. [CrossRef] [PubMed]

17. Lindeberg, S.; Jönsson, T.; Granfeldt, Y.; Borgstrand, E.; Soffman, J.; Sjöström, K.; Ahrén, B. A Palaeolithic diet improves glucose tolerance more than a Mediterranean-like diet in individuals with ischaemic heart disease. Diabetologia 2007, 50, 1795-1807. [CrossRef] [PubMed] 
18. Masharani, U.; Sherchan, P.; Schloetter, M.; Stratford, S.; Xiao, A.; Sebastian, A.; Nolte Kennedy, M.; Frassetto, L. Metabolic and physiologic effects from consuming a hunter-gatherer (Paleolithic)-type diet in type 2 diabetes. Eur. J. Clin. Nutr. 2015, 69, 944-948. [CrossRef] [PubMed]

19. Otten, J.; Mellberg, C.; Ryberg, M.; Sandberg, S.; Kullberg, J.; Lindahl, B.; Larsson, C.; Hauksson, J.; Olsson, T. Strong and persistent effect on liver fat with a Paleolithic diet during a two-year intervention. Int. J. Obes. 2016, 40, 747-753. [CrossRef]

20. Stomby, A.; Simonyte, K.; Mellberg, C.; Ryberg, M.; Stimson, R.H.; Larsson, C.; Lindahl, B.; Andrew, R.; Walker, B.R.; Olsson, T. Diet-induced weight loss has chronic tissue-specific effects on glucocorticoid metabolism in overweight postmenopausal women. Int. J. Obes. 2015, 39, 814-819. [CrossRef]

21. Ford, E.S.; Li, C.; Sattar, N. Metabolic syndrome and incident diabetes: Current state of the evidence. Diabetes Care 2008, 31, 1898-1904. [CrossRef]

22. Moher, D.; Liberati, A.; Tetzlaff, J.; Altman, D.G.; PRISMA Group. Preferred reporting items for systematic reviews and meta-analyses: The PRISMA statement. PLoS Med. 2009, 6, e1000097. [CrossRef]

23. Jamka, M.; Juruc, A.; Kulczynski, B. Effect of Paleo Diet on Glucose and Insulin Homeostasis; PROSPERO; CRD42019126412. 2019. Available online: https://www.crd.york.ac.uk/prospero/display_record.php? RecordID=126412 (accessed on 22 June 2019).

24. National Cholesterol Education Program (NCEP) Expert Panel on Detection, Treatment E and T of HBC in A (Adult, Panel III). Third Report of the National Cholesterol Education Program (NCEP) Expert Panel on Detection, Evaluation, and Treatment of High Blood Cholesterol in Adults (Adult Treatment Panel III) final report. Circulation 2002, 106, 3143-3421. [CrossRef]

25. Shuster, J.J. Review: Cochrane handbook for systematic reviews for interventions, Version 5.1.0, published 3/2011. Julian, P.T. Higgins and Sally Green, Editors. Res. Synth. Methods 2011, 2, 126-130. [CrossRef]

26. World Health Organization. Global Database on Body Mass Index; World Health Organization: Geneva, Switzerland, 2006; Available online: https://www.who.int/nutrition/databases/bmi/en/ (accessed on 7 January 2019).

27. Melmed, S.; Polonsky, K.S.; Larsen, P.R.; Kronenberg, H. Williams Textbook of Endocrinology; Elsevier: Philadelphia, PA, USA, 2015.

28. Gayoso-Diz, P.; Otero-González, A.; Rodriguez-Alvarez, M.X.; Gude, F.; García, F.; De Francisco, A.; Quintela, A.G. Insulin resistance (HOMA-IR) cut-off values and the metabolic syndrome in a general adult population: Effect of gender and age: EPIRCE cross-sectional study. BMC Endocr. Disord. 2013, $13,47$. [CrossRef] [PubMed]

29. DerSimonian, R.; Laird, N. Meta-analysis in clinical trials. Control Clin. Trials 1986, 7, 177-188. [CrossRef]

30. Higgins, J.P.T.; Thompson, S.G.; Deeks, J.J.; Altman, D.G. Measuring inconsistency in meta-analyses. BMJ 2003, 327, 557-560. [CrossRef]

31. McPherson, R.A.; Pincus, M.R. Henry's Clinical Diagnosis and Management by Laboratory Methods; Elsevier: Amsterdam, The Netherlands, 2017.

32. Wang, L.L.; Wang, Q.; Hong, Y.; Ojo, O.; Jiang, Q.; Hou, Y.Y.; Huang, Y.H.; Wang, X.H. The effect of low-carbohydrate diet on glycemic control in patients with type 2 diabetes mellitus. Nutrients 2018, 10, 661. [CrossRef]

33. Boden, G.; Sargrad, K.; Homko, C.; Mozzoli, M.; Stein, T.P. Effect of a low-carbohydrate diet on appetite, blood glucose levels, and insulin resistance in obese patients with type 2 diabetes. Ann. Intern. Med. 2005, 142, 403-411. [CrossRef]

34. Otten, J.; Andersson, J.; Ståhl, J.; Stomby, A.; Saleh, A.; Waling, M.; Ryberg, M.; Hauksson, J.; Svensson, M.; Johansson, B.; et al. Exercise training adds cardiometabolic benefits of a Paleolithic diet in type 2 diabetes mellitus. J. Am. Heart Assoc. 2019, 8, e010634. [CrossRef]

35. Gérard, C.; Vidal, H. Impact of gut microbiota on host glycemic control. Front. Endocrinol. 2019, 10, 29. [CrossRef]

36. Genoni, A.; Christophersen, C.T.; Lo, J.; Coghlan, M.; Boyce, M.C.; Bird, A.R.; Lyons-Wall, P.; Devine, A. Long-term Paleolithic diet is associated with lower resistant starch intake, different gut microbiota composition and increased serum TMAO concentrations. Eur. J. Nutr. 2019, 1-14. [CrossRef]

37. Ghaedi, E.; Mohammadi, M.; Mohammadi, H.; Ramezani-Jolfaie, N.; Malekzadeh, J.; Hosseinzadeh, M.; Salehi-Abargouei, A. Effects of a Paleolithic diet on cardiovascular disease risk factors: A systematic review and meta-analysis of randomized controlled trials. Adv. Nutr. 2019, 10, 634-646. [CrossRef] [PubMed]

38. Halton, T.L.; Hu, F.B. The effects of high protein diets on thermogenesis, satiety and weight loss: A critical review. J. Am. Coll. Nutr. 2004, 23, 373-385. [CrossRef] [PubMed] 
39. Clamp, L.D.; Hume, D.J.; Lambert, E.V.; Kroff, J. Enhanced insulin sensitivity in successful, long-term weight loss maintainers compared with matched controls with no weight loss history. Nutr. Diabetes 2017, 7, e282. [CrossRef] [PubMed]

40. Rader, D.J. Effect of insulin resistance, dyslipidemia, and intra-abdominal adiposity on the development of cardiovascular disease and diabetes mellitus. Am. J. Med. 2007, 120, S12-S18. [CrossRef]

41. Roberts, C.K.; Hevener, A.L.; Barnard, R.J. Metabolic syndrome and insulin resistance: Underlying causes and modification by exercise training. Compr. Physiol. 2013, 3, 1-58.

42. Zhang, X.; Li, J.; Zheng, S.; Luo, Q.; Zhou, C.; Wang, C. Fasting insulin, insulin resistance, and risk of cardiovascular or all-cause mortality in non-diabetic adults: A meta-analysis. Biosci. Rep. 2017, 37, BSR20170947. [CrossRef]

43. Blomquist, C.; Chorell, E.; Ryberg, M.; Mellberg, C.; Worrsjö, E.; Makoveichuk, E.; Larsson, C.; Lindahl, B.; Olivecrona, G.; Olsson, T. Decreased lipogenesis-promoting factors in adipose tissue in postmenopausal women with overweight on a Paleolithic-type diet. Eur. J. Nutr. 2018, 57, 2877-2886. [CrossRef]

44. Wallace, T.M.; Levy, J.C.; Matthews, D.R. Use and abuse of HOMA modeling. Diabetes Care 2004, 27, 1487-1495. [CrossRef]

45. Penno, G.; Solini, A.; Bonora, E.; Fondelli, C.; Orsi, E.; Zerbini, G.; Morano, S.; Cavalot, F.; Lamacchia, O.; Laviola, L. HbA1c variability as an independent correlate of nephropathy, but not retinopathy, in patients with type 2 diabetes: The Renal Insufficiency and Cardiovascular Events (RIACE) Italian Multicenter Study. Diabetes Care 2013, 36, 2301-2310. [CrossRef]

46. Schwingshackl, L.; Chaimani, A.; Hoffmann, G.; Schwedhelm, C.; Boeing, H. A network meta-analysis on the comparative efficacy of different dietary approaches on glycaemic control in patients with type 2 diabetes mellitus. Eur. J. Epidemiol. 2018, 33, 157-170. [CrossRef]

47. Otten, J.; Ryberg, M.; Mellberg, C.; Andersson, T.; Chorell, E.; Lindahl, B.; Larsson, C.; Holst, J.J.; Olsson, T. Postprandial levels of GLP-1, GIP and glucagon after 2 years of weight loss with a Paleolithic diet: A randomised controlled trial in healthy obese women. Eur. J. Endocrinol. 2019, 180, 417-427. [CrossRef] [PubMed]

(C) 2020 by the authors. Licensee MDPI, Basel, Switzerland. This article is an open access article distributed under the terms and conditions of the Creative Commons Attribution (CC BY) license (http://creativecommons.org/licenses/by/4.0/). 